\title{
Afrikanske langtids- præsidenter under pres
}

Holger Bernt Hansen

Spørgsmålet om antallet af perioder, hvori en afrikansk præsident sidder i embedet, bruges ofte som målestok, når 'demokratiets sande tilstand' i Afrika skal vurderes. Det noteres som et demokratisk underskud, når flere af de siddende præsidenter rask væk ophæver forfatningens begrænsning til to terminer og bevilger sig selv en 'third term' med mulighed for forlængelse ad libitum.

På det seneste har vi set en folkelig reaktion mod præsidenter uden åremålsbegrænsning, først og fremmest i Burkina Faso og Gambia, og det rejser spørgsmålet, hvor stor betydning denne reaktion indefra kan tillægges, og om den betegner et brud med mange års afrikansk praksis.

Problemets aktualitet og det opgør, der kræves for at ændre en årelang praksis, kom tydeligt frem under tidligere præsident Barack Obamas besøg i Kenya og Etiopien i juli 2015. I en af sine taler udtrykte han stor undren over, at præsidenter i Afrika har denne særlige tilbøjelighed til at klæbe til embedet i stedet for at respektere en begrænsning - også selv om de, som han sarkastisk tilføjede, havde sikret sig penge nok.
Reaktionen på Obamas tale giver en interessant afrikansk vinkel på spørgsmålet om 'third term'. At dømme efter det øjeblikkelige bifald fra de mange tusinde tilhørere var der ingen tvivl om, at de helt og fuldt tilsluttede sig Obamas synspunkt. Derimod sad de tilstedeværende præsidenter med stenansigter, der afspejlede misbilligelse, og efterfølgende karakteriserede flere af dem Obamas bemærkninger som indblanding $i$ interne anliggender og som et eksempel på den sædvanlige prædiken og påtvungne vestlige værdier.

$\square$ Problematikken om præsi-
denter uden åremålsbe-
grænsning har været en del
af demokratidebatten helt
fra uafhængighedens første
dage, og dermed har den
også været undergivet de
skiftende konjunkturer, der
har præget forholdet mellem
Afrika og Vesten.

På det seneste har Ugandas præsident, Yoweri Museveni, sat den reaktion i relief ved at henvise til Obamas efterfølger: "Museveni calls for 'Trump Therapi' for

Holger Bernt Hansen er professor emeritus, cand.theol. og dr.phil. Han var i 13 år leder af Center for Afrikastudier under Københavns Universitet. 


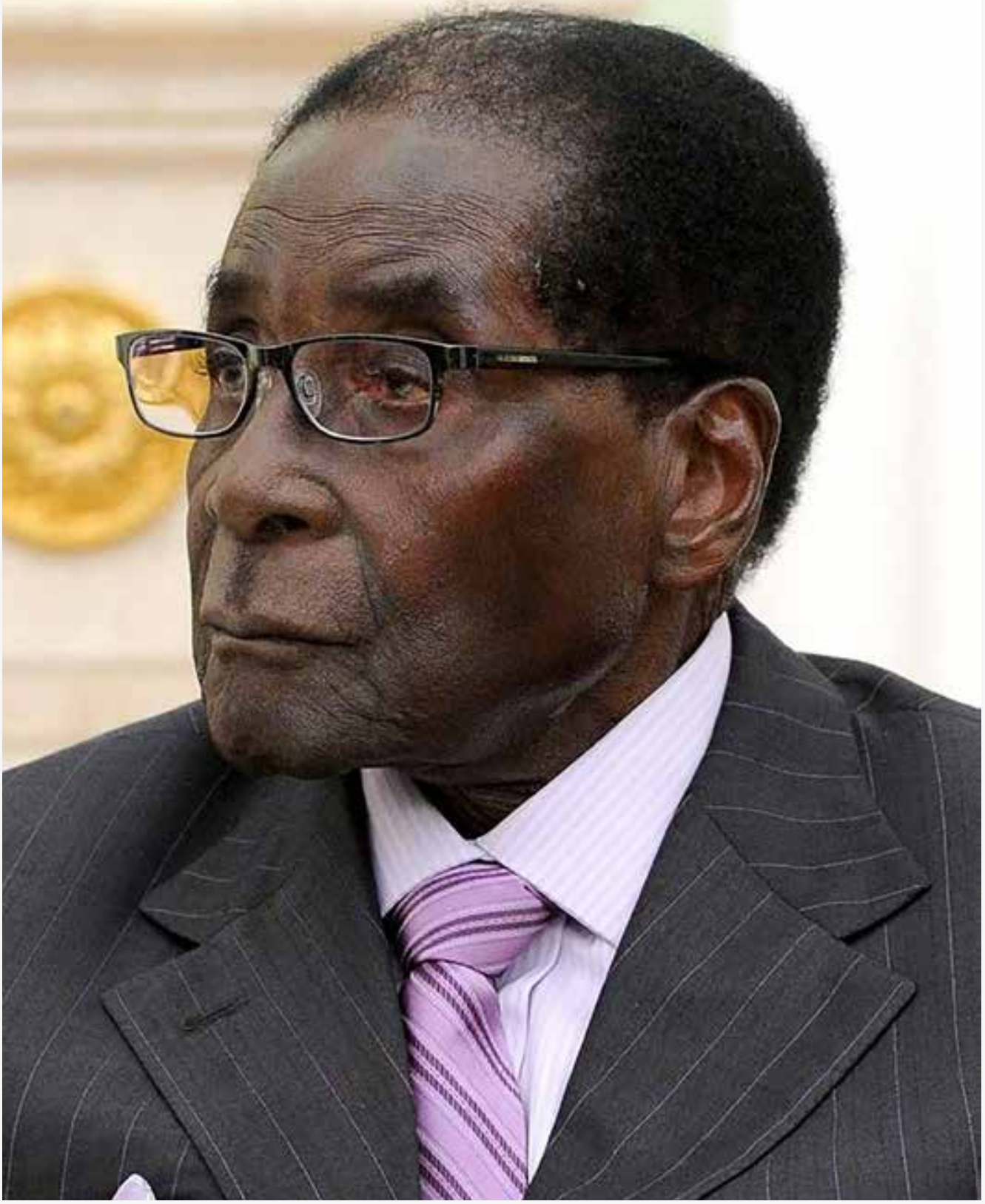

FOTO: www.kremlin.ru via Wikimedia Commons

Robert Mugabe anno 2015 
Liberals in the West" (overskrift i den kenyanske avis Daily Nation 20-02-17).

Problematikken om præsidenter uden åremålsbegrænsning har været en del af demokratidebatten helt fra uafhængighedens første dage, og dermed har den også været undergivet de skiftende konjunkturer, der har præget forholdet mellem Afrika og Vesten. Der bliver dog kun plads til at trække nogle generelle linjer frem fra forløbet uden mulighed for at dvæle ved de mange varianter, som Afrika er så rigt på. Afrika er ikke ét land, men består af 54 lande med forskellige potentialer for demokratisk udvikling. Med et udtryk hentet fra Europa kan Afrika betegnes som et kontinent i flere hastigheder også på demokratiseringens område.

\section{Uafhængighedens første fase}

Da uafhængighedsbølgen rullede ind over Afrika i 1960'erne, var det et hovedpunkt for de udgående kolonimagter, at de nye stater blev forankret i demokratiske principper, hvilket i praksis betød Westminster-modellen. Det viste sig dog hurtigt, at en sådan importeret demokratimodel ikke svarede til den virkelighed, som fandtes i de nye, meget uhomogene stater.

Flerpartisystemet viste sig funktionssvagt, da de politiske partier blev fanget af stærke etniske modsætninger og ofte udviklede sig til etnisk baserede interessegrupper. Der udviklede sig et stærkt centraliseret politisk system, der behøvede en stærk præsident, som var løftet over forfatningsmæssige begrænsninger med hensyn til varighed, og som kunne operere uden om de kontrolfunktioner, som parlament og domstole normalt varetager.

Det gav plads for hæren med dens monopol på magtmidler. Kort efter uafhængigheden blev hæren i stigende grad trukket ind på den politiske arena som garant og instrument for den siddende præsident. Skridtet til selv at tage magten blev meget kort, specielt når man derved kunne sikre sig større andele af de sparsomme goder. Specielt i Vestafrika kom det til en række militærkup, hvorefter lederen blev indsat som præsident, indtil næste kup forfremmede en ny person fra egne rækker. Det er fra denne periode, at traditionen med det stærke præsidentembede stammer - løftet over forfatningsmæssige begrænsninger og med militæret som garant og instrument for regimet. Og det er startpunktet for de senere så kendte langtidspræsidenter Blaise Compaoré i Burkina Faso og Yahya Jammeh i Gambia.

Senere i perioden dukkede der i det sydlige Afrika en anden type præsidenter op, der hentede deres legitimitet fra befrielsesbevægelsens kamp for uafhængighed. Der opstod et ideologisk defineret præsidentembede, der begrunder et tidsubegrænset monopol på magten og udelukker enhver tale om regimeskifte. Zimbabwes Robert Mugabe og Angolas dos Santos er protyper på denne kategori.

Når langtidspræsidenterne kunne bruge og ofte misbruge magten for egen vindings skyld, var årsagen det råderum, som den kolde krig skabte. Den nedskalerede Vestens krav om demokratiske spilleregler, alt imens de to rivaliserende stormagter i Afrika udspillede en slags stedfortræderkrig, der muliggjorde, at de afrikanske præsidenter kunne indgå undertiden ganske bizarre alliancer med hver sin stormagt.

Et af de mest kendte eksempler er præsident Mobutu i det daværende Zaire (nu Den Demokratiske Republik Congo), der for høj betaling og garanti for sikkerhed i embedet sikrede USA landets rige naturressourcer. Derfor får den kolde krigs ophør vidtrækkende betydning for Afrika og markerer starten på en ny æra. 


\section{Den anden befrielse}

Fremkomsten af en liberal verdensorden efter den kolde krig, undertiden benævnt en demokratisk verdensorden, skabte nye rammer for Vestens demokratiseringsprojekt i Afrika. Bistanden til Afrika blev ud over et økonomisk reformprogram fokuseret på treklangen demokrati, god regeringsførelse og menneskerettigheder. For at skabe realistiske omgivelser for demokratiseringsprocessen arbejdede man på at erstatte den statslige struktur, som havde udviklet sig i den første uafhængighedsperiode, med et nyt grundlag, der indebar en reduktion af den overdimensionerede stat og plads til både den private sektor og civilsamfundet.

Parallelt hermed var Afrika selv moden til et opgør med den hidtidige udvikling. Som udtrykket 'second liberation' markant understreger, var man indstillet på et opgør med de magtstrukturer, der havde udviklet sig, og specielt med den misbrug af magt, som de langtidssiddende præsidenter hjulpet af hæren havde gjort sig skyld i. Reformprocessen i 1990'erne blev ikke mindst drevet frem af en ny generation af afrikanske ledere: Meles Zenawi (Etiopien), Yoweri Museveni (Uganda) og Paul Kagame (Rwanda).

Centralt blandt reformerne stod udarbejdelsen af nye forfatninger, der skulle sikre parlamentarismen baseret på et flerpartisystem, garantere de almindelige rettigheder og sikre uafhængige institutioner, specielt domstole. I lyset af fortidens misbrug blev tre ting afgørende for at sikre den demokratiske orden. For det første lovfæstedes regelmæssige valg administreret af en uafhængig valgkommission. For det andet søgte man at definere militærets rolle som værende at tjene den til enhver tid siddende regering uden at kunne optræde i en politisk rolle. Og ikke mindst for det tredje fastlagde man valgperiodens længde og begrænsede antallet af præsidentterminer til to.

Netop disse tre punkter bliver afgørende både for omsætningen af de demokratiske principper til praksis, og ikke mindst bliver de af såvel afrikanerne som Vesten benyttet som kriterier for at måle fremskridt eller tilbageskridt på den demokratiske skala.

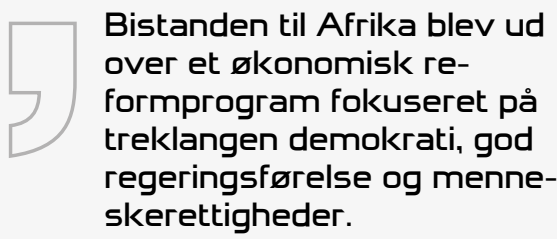

Sammenfattende kan man som et varigt resultat af 'den anden befrielse' fremhæve to ting. For det første skal Afrikas fremtidige udvikling baseres på demokratiske værdier og principper. Den politiske magt udgår fra folket, hvilket kommer til udtryk gennem regelmæssige valg. Derfor bliver valg det vigtigste omdrejningspunkt i den fremtidige politiske udvikling.

For det andet bliver det demokratiske grundlag så at sige lovfæstet i Den Afrikanske Unions (AU) charter fra 2001. Heri fastslås, at valg skal respekteres, og at regeringsskifter skal ske på et forfatningsmæssigt grundlag. Militærkup bliver således udelukket. I sådanne tilfælde og i det hele taget ved forfatningsstridig adfærd er første sanktion, at vedkommende stat suspenderes fra AU.

Yderligere kan sanktionen udvides til militær intervention, hvilket må betegnes som et vidtgående skridt, da det bryder med reglen om ikke-indblanding i et lands indre anliggender. At dette ikke blot er en teoretisk mulighed, er begivenhederne i Gambia i januar 2017 et eksempel på. 
På den anden side er der klare begrænsninger i AU's muligheder for at korrigere den demokratiske kurs. Det er især påfaldende, at der i chartret ikke tages stilling til princippet om præsidentembedets begrænsning til to terminer. Derfor kommer der ingen reaktion, når reglen sættes ud af kraft gennem forfatningsændringer. Tværtimod. Den kendsgerning, at 14 af de præsidenter, der underskrev chartret i 2001, stadig sidder i embedet i 2017, bekræfter, at det er op til de enkelte lande at indføre og administrere to-terminsreglen.

I den videre drøftelse må det derfor lægges til grund, at der er forskel på at vedkende sig demokratiske principper som overordnet grundlag for udviklingen, hvilket Afrika har gjort i modsætning til andre dele af verden, og den demokratimodel og demokratiske praksis, som man vælger ved den konkrete indretning af sit demokrati.

\section{Fremgang for to-terminsreglen}

Fra såvel vestlige donorer som fra indflydelsesrige afrikanske ledere lå der en stærk opfordring til at indføre to-terminsreglen som den bedste vej til et velfungerende demokrati. Denne opfordring prellede naturligvis af på de såkaldte 'dinosaurer', hvad enten de var rundet af militæret eller befrielsesbevægelsen. Det længste, de strakte sig, var at indføre valg som en demokratisk fernis, men med en indbygget sikring af resultatet, om nødvendigt med militærets hjælp, således at systemet kunne fortsætte som hidtil - enkelte har ikke været fremmede for at antyde på livstid. På den anden side er det også denne kategori, der er mest sårbar, når forandringer sætter ind.

Den generelle tendens er, at to-terminsreglen medtages under de talrige forfatningsændringer, der sker i løbet af
1990 'erne, og at den i stigende grad efterleves. Det gælder i Østafrika først og fremmest Tanzania efterfulgt af Kenya. men tyngepunktet findes i Vestafrika anført af lande som Ghana og Nigeria. Afgørende er, at valgresultatet respekteres, nogle gange via domstolene. Det gælder også i de tilfælde, hvor udfaldet medfører et regimeskifte, som det for nyligt var tilfældet i netop Nigeria og Ghana. Den samme opslutning om to-terminsbegrænsningen ses også i lande, som nyligt er kommet ud af diverse kriser, eksempelvis Liberia, Elfenbenskysten, Burkina Faso og Senegal.

Gruppen af lande på positivlisten står dog over for en udfordring, der vokser sig stærkere, og som især viser sig, når valgresultatet bliver et tæt løb. For det første bliver penge og køb af stemmer, baseret på en stigende korruption, mere reglen end undtagelsen. Dette leder for det andet til en stigende usikkerhed om valghandlingens forskellige faser lige fra udarbejdelsen af valglister over selve afstemningen til optællingen af stemmer. Der er generelt tale om en voksende mistillid ikke mindst i kølvandet på brugen af elektroniske hjælpemidler, som åbner for subtile og sofistikerede metoder til manipulation, som selv erfarne valgobservatører har vanskeligt ved at gennemskue.

\section{Tilbageslag for to-terminsreglen}

Debatten om de langtidssiddende præsidenter har faet en fornyet aktualitet fra de tilfælde, hvor stater ligefrem har ophævet to-terminsbegrænsningen. Det gælder Uganda, Rwanda og i nogen grad Etiopien, netop de tre lande, hvis præsidenter var bannerførere under 'den anden befrielse'.

Ugandas case er særlig interessant, fordi den peger på de vestlige donorers mind- 
skede indflydelse. I den nye forfatning fra 1996 indførtes to-terminsbegrænsningen som en selvfølge, men donorerne måtte modvilligt acceptere, at politiske partier blev suspenderet, og at man i stedet fik et 'no party system' med guerillabevægelsen som den altomfattende struktur.

Da præsident Museveni nærmede sig udløbet af sin anden periode, startede en kampagne for at ophæve begrænsningen, idet præsidenten endnu ikke havde fuldført sin mission og i øvrigt var garant for freden i det splittede land. Donorerne gik stærkt imod, men prioriterede i situationen indførelse af et flerparti system. Det uudtalte kompromis blev, at begge parter blev tilgodeset ved forfatningsændringen.

\section{Øget kontrol og indskrænk- ning i udøvelsen af alminde- lige rettigheder vinder frem. Det gælder pressefriheden og forsamlingsfriheden, ikke mindst retten til at mødes og demonstrere.}

Museveni er nu nået til sin femte valgperiode, der startede i maj 2016. Suppleret med erfaringer fra Rwanda, som på tilsvarende vis har ophævet begrænsningen af præsidentielle terminer, er tiden inde til både at se på de faktorer, der muliggør fremvæksten af et sådant altdominerende præsidentembede, og at identificere de ændrede konjunkturer, der giver plads til en sådan udvikling.

Hvad det første angår, har tre faktorer vist sig afgørende:

- Det allerede nævnte misbrug af valg udvikles nærmest til perfektion under brug af forskellige slags repressive metoder. Det har faet sudanesiske Mo Ibrahim, der er kendt for sin pionerindsats for at fremme demokratiet i Afrika, til i sin rapport for 2016 om 'demokratiets sande tilstand' at sammenligne nutidens autoritære præsidenter med den forudgående generation: hvor de gamle stjal kassen, stjæler de nuværende valgene.

- Den kontrollerende indflydelse fra institutioner som parlament og domstole svækkes, hvorimod sikkerhedsapparatet udbygges og udstyres med omfattende beføjelser.

- Øget kontrol og indskrænkning i udøvelsen af almindelige rettigheder vinder frem. Det gælder pressefriheden og forsamlingsfriheden, ikke mindst retten til at mødes og demonstrere. Det har konsekvenser for politisk aktivitet i almindelighed og især for oppositionspartiernes arbejdsmuligheder. Et nyt, men ikke overraskende middel, der i stigende grad tages i anvendelse, er lukning af netadgang og af mobiltelefonsystemet. Begrundelsen for disse indskrænkninger anføres ofte at være frygten for uro og optøjer, men bag ligger en markant udvidelse af uro-begrebet. Dertil kommer, at nogle lande anfører terrortruslen som begrundelse.

Disse tre faktorer ses ikke kun i lande, hvor 'third term'-problematikken er aktuel; der er tale om en generel tendens i varierende udformning på store dele af kontinentet. Dette leder til at se nærmere på de konjunkturer, som betinger disse ændringer i den demokratiske udvikling og åbner for en genkomst af langtidspræsidenter.

\section{Ændrede konjunkturer}

Idegrundlag og prioriteringer har ændret sig gennem de senere år og begynder at få en effekt både i Vesten og i Afri$\mathrm{ka}$. Bistanden er ved at tabe sin betydning som pressions- og sanktionsmiddel. Såvel 
de såkaldte remitter som de direkte investeringer overstiger hver for sig ulandsbistanden, og den har ikke længere en 'gidselværdi, som det er blevet udtrykt fra afrikansk hold. Ej heller vejer Vestens demokratiske stemme lige så stærkt som tidligere. Afrika noterer sig inkonsistens i

\section{$\square$ Såvel de såkaldte remitter som de direkte investeringer overstiger hver for sig ulandsbistanden, og den har ikke længere en 'gidsel- værdi', som det er blevet udtrykt fra afrikansk hold.}

den vestlige praktisering af det liberale demokrati og mærker helt konkret den ændrede prioritering i samarbejdet i forlængelse af opprioriteringen af migrations-, sikkerheds- og terrordagsordenen.

Generelt kan ændringerne i Vestens holdninger og ageren sammenfattes ved brug af en skala, der i den ene ende som startpunkt har værdier og i den anden ende egeninteresser. Vesten har flyttet sig på skalaen og befinder sig nu langt tættere på egeninteresser uden endnu at have fundet et nyt balancepunkt. Derfor kommer det undertiden til udbrud og reaktioner, som bærer præg af det gamle værdigrundlag, hvilket ikke fremmer den gensidige tillid og den nye form for samarbejde, som er påkrævet.

Men man bør fra Vestens side ikke negligere, at der i Afrika er en udbredt mistillid til Vestens motiver og handlinger. Museveni har med sin karakteristiske sprogbrug givet udtryk for denne stemning i en nylig blok: “...by the Western Liberals trying to impose all their views and values on everybody in the World, they generate not convergence but divergence and even conflict". Denne reaktion er båret af den kendsgerning, at Afrika har fået et alternativ til Vesten gennem de nye vækstøkonomiers indtog, i særlig grad Kina. De har bidraget til imponerende økonomiske vækstrater i en række lande. Samtidig er der tale om et samarbejde, som ikke inkluderer betingelser om demokrati og overholdelse af rettigheder.

De mange kontakter med Asien, har rejst tvivl om en af de helt afgørende præmisser for Vestens indsats i Afrika: den direkte forbindelse mellem demokrati og udvikling. Dette kan også formuleres som et dilemma mellem en demokratisk dagsorden og en udviklingsdagsorden.

Rwanda og Etiopien har med stor effekt benhårdt prioriteret udviklingsdagsordenen med henvisning til behovet for hurtig genopbygning efter kriseår, hvilket har stillet vestlige donorer over for store udfordringer, som ikke altid har været håndteret med passende smidighed. Den samme prioritering af udviklingsdagsordenen er ved at brede sig til lande, som fortsat respekterer regelmæssige nyvalg til præsidentposten. Henvisninger til demokratiske rettigheder må ikke stille sig i vejen for den udvikling, som en nyvalgt præsident under valgkampen har lovet befolkningen, uanset at det giver underskud på den demokratiske konto.

Netop håndteringen af den afrikanske prioritering mellem de to dagsordener er Vestens store, aktuelle udfordring.

\section{'Africa Uprising'}

Hverken presset fra Vesten eller initiativer fra afrikansk hold ser således ud til at kunne løse op for den fastfrysning, der for øjeblikket er mærkbar for demokratiet i Afrika. Det flytter imidlertid fokus til den interne udvikling i Afrika, hvorfra et nyt pres for forandring er på vej - nog- 
le går så vidt som at tale om 'den tredje befrielse'. Nylige begivenheder i Burkina Faso og Gambia bekræfter, at en folkelig reaktion er ved at vinde frem

Da Blaise Compaoré i 2014 efter 27 år som Burkina Fasos præsident endnu engang ville bryde terminsbegrænsningen for at fortsætte i en ny periode, kom det $\mathrm{i}$ parlamentet til alvorlig uro, som blev nedkæmpet af præsidentens specielle garde. Senere kaldte oppositionen folk på gaderne, og for første gang så man tusinder af mennesker trodse truslen om hærens indgriben og gå i demonstration for at få gennemført et regulært præsidentvalg.

Lige så bemærkelsesværdigt er det, at den ordinære hær støttede de demonstrerendes krav om forandring. Blaise Compaoré måtte gå i landflygtighed, og med støtte fra AU og ikke mindst fra den regionale samarbejdsorganisation Economic Community Of West African States (ECOWAS) blev terminsbegrænsningen genindført og nyvalg afholdt.

Ud over hærens svigt af præsidenten og alliancen med de demonstrerende er det bemærkelsesværdigt, at folk trods truslen om styrets voldelige indgriben gav så massivt udtryk for deres utilfredshed og krav om forandring. For første gang så man en markant folkelig protest, som stillede en langtidspræsident til regnskab: hvad havde han udrettet gennem sine mange år, som begrundede genvalg; han havde fremmet en korruptionskultur, der forgyldte magtens indercirkel; og ikke mindst bestred man det ejerskab til præsidentembedet, som han lagde for dagen ved at kræve en ny periode.

En lignende folkelig reaktion kom, da Gambias præsident gennem 22 år, Yahya Jammeh, indstillede sig selv til en ny periode. Ved præsidentvalget i december 2016 mødte folk trods skræmmekampag- ner op i stort tal ved afstemningsstederne, og trods alle bestræbelser for at sikre det forudbestemte resultat blev den samlede oppositions kandidat valgt som ny præsident. Da Jammeh ikke accepterede resultatet, men ønskede en ekstra chance gennem et nyvalg, udtrykte AU nok misbilligelse, men det var ECOWAS, som gennem en bemærkelsesværdig håndfast indsats løste krisen. Medlemslandenes præsidenter, der selv er blevet valgt $\mathrm{i}$ overensstemmelse med to-terminsreglen, krævede, at valgresultatet blev respekteret, og de bakkede deres ultimatum op ved at sende en militær styrke ind i Gambia.

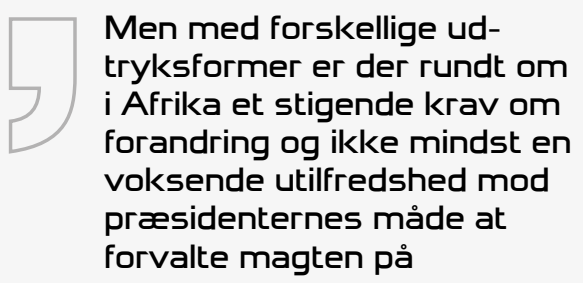

Ikke blot var der opbakning til den folkelige protest, der fandt udtryk ved valget, men ECOWAS viste en handlekraft til at sikre overholdelse af demokratiske spilleregler, som AU og ECOWAS' parallelorganisation i Østafrika ikke udviste i den tilsvarende situation i Burundi, hvor overtrædelse af to-terminsreglen har bragt landet ud i en ødelæggende, folkemordslignende krise.

Forklaringen er, at i Gambias tilfælde var beslutningstagerne alene de vestafrikanske præsidenter med deres demokratiske 'credentials', mens blokeringen i tilfældet Burundi kommer fra præsidenter, der selv har ophævet to-terminsbegrænsningen eller aldrig anerkendt den.

I de to nævnte tilfælde er det helt klart de folkelige protester mod præsidenternes underkendelse af demokratiske spil- 
leregler, der har vejet tungt $\mathrm{i}$ beslutningen om at handle, selv om også andre motiver har spillet en rolle. Men med forskellige udtryksformer er der rundt om i Afrika et stigende krav om forandring og ikke mindst en voksende utilfredshed mod præsidenternes måde at forvalte magten på. Selv med risiko for fængslinger og hårdhændet behandling af de stadig mere nærværende sikkerhedsstyrker vover folk at gå på gaderne. Denne folkelige reaktion har fået betegnelsen 'Africa Uprising', og den tolkes undertiden som udtryk for, at Afrika er moden til 'den tredje befrielse'.

\section{Fremtidens udfordring}

Denne folkelige protest, som næppe kan kaldes en bevægelse, er ikke et kortvarigt fænomen og ej heller, som det undertiden hævdes, alene båret af en middelklasse, der er ledende i overgangen til demokrati. Den er også båret af fattigere og mere marginaliserede dele af bybefolkningen, og den har sit udspring i de markante ændringer, der finder sted i de afrikanske samfund i disse år. Pladsen tillader kun at nævne tre væsentlige og sammenhængende elementer i denne forandringsproces:

- Den hastigt voksende urbanisering, der samler mange mennesker på et begrænset område og muliggør nye gruppeog fællesskabsdannelser.

- Befolkningsvækstens eksplosive karakter med en ungdomsgeneration, som udgør 60 pct. af befolkningen under 25 år, og som er rimeligt veluddannet, men i høj grad uden job.

- Eksplosionen i brugen af elektroniske midler med adgang til internet og ikke mindst mobiltelefoner. Her er der tale om en forandringskraft af revolutionær karakter, som er med til at skabe en helt ny situation. Der er tale om et væsentligt middel til at mobilisere befolkningen, især de unge. Men ikke mindst opstår der hos folk en bevidsthed om deres egen undertrykkelse og i forlængelse heraf tilsvarende store forventninger til en bedre fremtid.

Disse forandringer indefra får uvægerligt en politisk betydning, som eksemplerne fra Burkina Faso og Gambia viser. Men de folkelige protester skal ikke kun måles på grundlag af deres resultater. Der er tale om folkelige reaktioner uden egentligt lederskab og uden bestemte programpunkter. De er båret af kravet om forandring og af en bevidsthed om, at det er nødvendigt at være aktive og reagere mod, hvad der kan karakteriseres som 'African states, captured by elites and dependant on violence.' Opgøret er mere mod det aktuelle misbrug af magt end for langsigtede demokratiske mål.

Magthaverne har reageret på to måder. På den ene side er det karakteristisk, at ved de seneste valgkampagner har løfter om bekæmpelse af korruption været fremtrædende, uden at der dog efterfølgende med få undtagelser er vist stor handlekraft. På den anden side er der sket en yderligere begrænsning af forskellige rettigheder og en forstærket brug af voldelige midler, alt imens der lukkes af for adgang til net og mobilsystem.

Den faktor, der bliver helt afgørende for den fremtidige udvikling, er den store ungdomsgeneration uden job og uden mange fremtidsudsigter. Den kan enten blive en trækkraft for kontinentets udvikling i almindelighed og blive centrale aktører i opgøret mod de enevældige præsidenters magtudøvelse, eller den kan være kilde til ustabilitet og mere vold.

Fra lederside tales der meget om det første, men i praksis gøres der mest for det sidste. Ved de seneste valg har grupper af unge været aktive hyret af de politiske ledere fra såvel regering som opposition. De 
bruges til at true vælgere til at stemme rigtigt, og de er klar til at gå i aktion og skabe uro, hvis resultatet falder 'forkert' ud. Der er tale om en slags militsdannelse, som øger tendensen til militarisering af det politiske liv i Afrika. Regeringspartiets etablering af et system med 'Crime Preventer' rundt om i Uganda under valget i 2016 tjener blot som et enkelt eksempel.

\section{Quid novi ex Africa?}

Dette klassiske spørgsmål besvares oftest med, at der altid er nyt fra Afrika. Med fokus på præsidentperioder bliver det en blanding af gode og dårlige nyheder om fremskridt og tilbageslag. Afrika befinder sig i en overgangsfase på en række områder, hvor det endnu ikke er klart, hvordan udfaldet vil blive. Det gælder ikke mindst på demokratiets område, hvor forskellige former efterprøves i bestræbelserne for at udvikle den model, som passer til afrikanske realiteter præget af samfund under forandring.

Denne proces sker i samspil med en ny verdensorden under udvikling, hvor Afrika skal finde sin plads. Og den sker under indflydelse af ændringer i det værdi- og normsæt, som hidtil har været gældende i forholdet mellem Afrika og Vesten. 